\title{
Determinants of Mandarin Productivity and Causes of Citrus Decline in Parbat District, Nepal
}

\author{
Panth Bishnu Prasad ${ }^{1 *}$ and Dhakal Shiva Chandra ${ }^{2}$ \\ ${ }^{1}$ Centre for Agricultural Research and Education, Bharatpur, Chitwan, Nepal \\ ${ }^{2}$ Agriculture and Forestry University, Rampur, Chitwan, Nepal
}

*Corresponding Author: Panth Bishnu Prasad, Centre for Agricultural Research and Education, Bharatpur, Chitwan, Nepal.

Received: August 12, 2019; Published: September 05, 2019

DOI: 10.31080/ASAG.2019.03.0638

\begin{abstract}
A survey research was conducted in Baskharka and Purnagaun Village Development Committees of Parbat district to access determinants of productivity and causes of citrus decline. The general objective of the research was to know the different management practices and dimensions of productivity under mandarin in Parbat district. Total sample size of 120 was selected by using simple random sampling. The primary data were collected using pretested questionnaire in 2018. Majority of respondents (65\%) had agriculture as a primary occupation for income and respondents had been involved in mandarin farming since 8 to 40 years. The land holding under mandarin orchard per household and livestock holding per household were found to 0.39 ha and 5.65, respectively. The productivity and price per kg mandarin was found $7.26 \mathrm{mt} /$ ha and NRs.102.5, respectively. Productivity of mandarin was found significantly associated positively with years of involvement $(p=0.01)$ in mandarin farming, pruning in effective time period $(p=0.01)$, and negatively associated with manuring (0.09), and intercropping practices $(p=0.01)$. Citrus decline ( $p=0.004)$ was found to be significant with number of years in mandarin farming. Bugs, Powdery mildew, lack of insurance and transportation were major problems of mandarin production in the study area. The study pointed out that the mandarin farming could be highly profitable enterprise in Parbat district of Nepal and its commercialization can be promoted by addressing the different factors affecting its management practices.
\end{abstract}

Keywords: Productivity; Dimensions; Citrus Decline; Income

\section{Introduction}

Mandarin orange is the most important and highly commercialized fruit among the fruit crops grown in the mid hilly region of Nepal. Fruits contribute about 7\% AGDP (MoAC, 2010). The total area under fruit cultivation in Nepal is 119114 ha and has production of $10,96,774 \mathrm{mt}$ with productivity of $9.21 \mathrm{mt} / \mathrm{ha}$ in FY 2072/73 [1]. Horticultural commodities contribute 14\% of the total agriculture GDP and of which fruit only contributes 7.04\% GDP [2]. Citrus has been grown in 62 districts: Dhankuta, Terathum, Sindhuli, Ramechhap, Dhading, Kavre, Gorkha, Lamjung,
Tanahun, Kaski, Syangja, Myagdi, Palpa, Salyan, Dailekh, Baitadi, Dadeldhura are the major producers [3]; important cash crop for the hill farmers of Nepal contributing the $26.84 \%$ of the total fresh fruits production. The total area under citrus, production and productivity of citrus are 39035 hectare, 0.22 million $\mathrm{mt}$ and $8.82 \mathrm{mt}$ per ha with mandarin contributing to 25408 hectare in total area, 0.15 million $\mathrm{mt}$ in production with productivity of 9.03 ton per hectare [4]. The Agriculture Prospective Plan (APP, 19952015) on which agriculture development had been framed, had prioritized the mandarin production in the mid hills of Nepal. Now 
the priority has been carried by the Agriculture Development Strategy (ADS, 2014). The area under this crop is increasing in Nepal, which is mainly due to its high demand in National and international market. Mandarin is a subtropical crop growing in an area bearing a deep well drained loamy soils with $\mathrm{pH}$ between 5.5 and 6.5, lying at 700-1500 m height, receiving a rainfall of about $125 \mathrm{~cm}$ to $180 \mathrm{~cm}$ and where winter is mild (no frost) and there is no strong, hot winds during summer [5]. The mid-hill region (1000 to $1500 \mathrm{~m}$ altitude) has a comparative advantage in the cultivation of citrus fruits, especially mandarin and sweet orange. These are grown in almost all mid-hill areas ( 900 to $1400 \mathrm{~m}$ ) of the country. The mid-hill region, which accounts about 1.5 million ha is quite suitable for citrus cultivation [6]. The total mandarin cultivation area in Nepal is 25407.9 ha in with 16527.5 ha is productive and $149315.5 \mathrm{mt}$ production under which mandarin account $63.54 \%$ [2]. The national average production of mandarin is $9.0 \mathrm{mt} / \mathrm{ha}$ [2] which is much lower than the potential yield and yield achieved by neighboring countries of South Asia. The production and productivity of the mandarin has been in declining rate in Nepal. It was $11.2 \mathrm{mt} /$ ha in 2011 but has decreased significantly to as low as $8.8 \mathrm{mt} /$ ha in 2014 (MOAD, 2013). Various factors are responsible for such reduction ranging from improper management to citrus greening. Parbat has total area for mandarin is 715 ha where productive area is 478 ha with production of $3610 \mathrm{mt}$ fruits and $7.6 \mathrm{mt} / \mathrm{ha}$ [1]. The production of citrus is increased by more than two folds in last decade which is mainly contributed with increase in area of production despite of the slow growing productivity. The mid-hill region of Nepal (1000 to 1500 meters) altitude has a comparative advantage for citrus cultivation when compared to food grain crops like rice, wheat, maize and found to be more profitable $[7,8]$. A survey by [9] in Parbat district found that the problem for production to be yellowing of the branches after fruiting along with the fruit drop that has led to the decline. Mandarin orange and other citrus fruits species are well flourished in this region. The increasing demand of the fruits in nearby districts Myagdi (Beni), Kaski (Pokhara) and in Kusma (Parbat) has made farmers positive towards commercialization of the citrus fruits especially mandarin in this regions. Despite of lack of technical assistance and guidance has lead farmers to the poor orchard management and has cause the decrease in the production over the years. Many trees in orchard have either turned into dried skeleton or are on the verge of die back. Those remaining productive trees have also not been able to produce to their potential. About 1 meter basin is prepared around the trees to provide mulching, irrigation and fertilizers [10]. Farm yard manure is most common form of organic manure applied in mid-hills of Nepal. Inter cropping should be practiced in the early stages of the orchard (up to $5^{\text {th }}$ year). The best time for pruning is just after harvest. In Nepal, citrus trees are not generally pruned but to give an ideal shape and to keep the tree healthy, tree training and pruning is essential. An ideal mandarin tree should be low headed with dome like crown [11]. Despite many diseases reported to attack citrus crop in Nepal. Huanglongbing (greening) disease is the number one threat to the citrus industry followed by Phytophthora inducing diseases [12]. Other diseases associated with citrus decline in Nepal are Tristeza, canker, twig blight and powdery mildew disease. Anthracnose, Sooty mould, Pink diseases, gummosis, scab diseases are the other diseases for declining citrus production and its quality [13]. More than 250 insects have been recorded on various citrus species in India [14]. Different insect pests cause damage to citrus leading to their decline. Among them, psylla, citrus leaf miner, blackfly, lemon butterfly, bark eating caterpillar, aphids, thrips, fruit sucking moth and citrus mites attack citrus trees regularly from nursery stage to the harvest causing cognizable damage, posing a serious threat to citrus cultivation [15]. Lime materials should be applied if the orchard is on sloping land from which soil cation have been leached and where the soil $\mathrm{p}^{\mathrm{H}}$ is lower than 5 indicates strong acidity [16]. Liming materials should be applied after the fruit is harvested. In terms of quantity, lime is normally recommended @5-7 kg/ tree [11]. Mixing manure or compost with the lime materials is recommended. Mulching around tree basins with organic materials such as straw, saw dust, rice, hulls, dry leaves, and compost will help to retain moisture by reducing evaporation, reducing run-off water and soil erosion [17]. In Nepal, the best time for mulching citrus orchard is Sept-Oct. Mulching the soil conserves the moisture to the extent of approximately $10 \%$ against non-mulching [18]. The total farmers, their education level, assistance from the technical specialists, the income generation determines the irrigation adoption and the intensification of the technological citrus production. The commercialization channels, inclusion on different organizations, area under cultivation and the price factor does not make a difference in technological adoption process (Fabiana Ribeiro Rossi, 2014). 
The general objective of the research is to know the different factors affecting productivity and dimensions of its dimensions and the specific objectives were

- To know different management practices adapted by mandarin farmers in Parbat

- To access factors determining productivity of mandarin orange in the study area

- To investigate the present scenario and causes of citrus decline

\section{Methodology}

The research was carried in Parbat district: Orange block at Baskharka VDC on the basis of the recognized production site for orange through PMAMP. Parbat lies in the hilly region and extends from $28^{\circ} 00^{\prime \prime} 19^{\prime \prime}$ North to $28^{\circ} 23^{\prime \prime} 59^{\prime \prime}$ North latitude and $83^{\circ} 33^{\prime \prime}$ 40 "east to $83^{\circ} 49^{\prime \prime} 30^{\prime \prime}$ east longitude. This district is stretched over mid-hill and terrain ranges from $520 \mathrm{~m}$ to $3300 \mathrm{~m}$ above average mean sea level. It has annual rainfall of $2500 \mathrm{~mm}$ and temperature in between $7.3^{\circ} \mathrm{C}$ to $32.3^{\circ} \mathrm{C}$ (DADO, 2072). It covers an area of $494 \mathrm{sq}$. $\mathrm{km}$ and population of 157826 including 47 VDCs. Population density is 320 per sq. $\mathrm{km}[19,20]$. Pre survey field visits was conducted to gather preliminary information regarding the demographic, sociocultural, and topographical settings of the site. This information was used in preparing questionnaires and deciding on sampling framework. The research was carried in Parbat district: Orange block at Baskharka VDC on the basis of the recognized production site for orange through PMAMP. The sample was selected on the basis of production area, productivity, problem recognition and among the total citrus growing farmers 120 mandarin growing farmers were selected. The questionnaire was pre-tested prior to field survey for checking the reliability and validity and then necessary adjustment was made as per the requirements after administering the questionnaire to the $5 \%$ farmers of vicinity area. One comprehensive Focus Group Discussion (FGD) was conducted at the study area after completing the field survey to verify the result obtained from field survey, to know the various factors leading to citrus decline. In the FGD participants was local citrus farmers, all ethnic groups and both male and female are included. The primary data was obtained from the questionnaire regarding numbers of factors causing citrus decline in that area. Secondary information was collected from the various published materials like journals, research articles, proceedings of various NGOs and INGOs, reports of DADO. Data was fed to Microsoft excel and analysis was done by using statistical packages for social sciences (SPSS) and STATA 12. Correlation, t-test, and Logistic Regression were used to derive inference needed.

\section{Result and Discussions}

It was found that $83 \%$ of the respondents were male and $17 \%$ were female with average age as 48 years. $67 \%$ of the respondents were economically active (16-59 years of age) while $13 \%$ belonged to economically inactive population (above 60 years of age). The household size on the survey area was on an average 6 persons per household. The society was dominant by $58 \%$ Chhetri community followed by $27 \%$ Janjatis, $13 \%$ Brahmins and 2\% Dalits. The education level of the surveyed people showed that $3 \%$ were graduates, $12 \%$ were bachelors, $38 \%$ had received secondary school education, 35\% had received primary education, and $8 \%$ had higher education level while $3 \%$ of the respondents had not received any formal education. The $65 \%$ population was involved in agriculture as primary income source while rest population was found involved in either business or services. The average LSU was found to be 5.65. The average land holding was 14.49 ropani per household with mandarin occupying an area of 7.69 ropani on average and on average 48 external labours were used in addition to the 3.58 active family members.

Farmers in the study area had long been involved in mandarin cultivation with average age of orchard was 25.63 years. $78 \%$ of the field were facing north and 34 plants were found per ropani where $47.22 \%$ mandarin trees were at bearing stage. Only $8.33 \%$ population had knowledge regarding the certification of planting materials and planting was done in 1 meter trench dried for a week filled with $14.46 \mathrm{~kg}$ manure on average and planting was followed by irrigation. $96.33 \%$ farmers were found using the manure on average less than $30 \mathrm{~kg}$. $83.33 \%$ orchard were dependent on rainfall where only $25.07 \%$ was irrigated land and $80 \%$ farmers were practicing canal or pipe irrigation while $20 \%$ were shifted to sprinkler irrigation. $90 \%$ farmers were found practicing weeding two times: once in winter after harvesting and manuring and once at the rainy season.85\% farmers were practicing intercropping and $28.33 \%$ farmers were preferring productive leguminous crops for intercropping. 
Prunning were practiced by $61.67 \%$ farmers where only $75.67 \%$ farmers were found prunning at the effective time period. $76.67 \%$ farmers use Bordeaux mixture or paste in the mandarin field and about $18.33 \%$ farmers use the Bordeaux mixture even without the prunning. $71.67 \%$ mandarin field were moderately affected by insects where the trees were highly affected by bug, followed by leaf miner with moderate infestation and aphid with low infestation and insects like mealy bug and scale insects had not made any infestation at economic level. Similarly powdery mildew has highly affected the trees mainly during rainy season, followed by foot rot with medium infestation due to poor irrigation practices and intercropping and canker with low infestation. Disease like pink disease and stem rot are not reported at economic injury level. Use of jholmol, titepati, ash, and the use of Bordeaux components was seen in mandarin orchard by $76.67 \%$ of the total respondents. Chemical method of control was not found in the study area. Poor control of disease and pest had led to low productivity of this reason.

The average price last year was NRs.80.5 and average price this year was NRs.102.5 for every kg mandarin and major maket to sell mandarin was Pokhara. 38.33\% farmers were practising contract farming with middleman The survey area was $6 \mathrm{~km}$ away from the main road. On average $42.67 \%$ income source was from mandarin farming. 93\% individuals were engaged in co-operatives and there was no provison of loan for mandarin farming. The members from $43.33 \%$ houshold were found to be in foreign seeking job for supporting the family.

\section{Dimension of productivity}

The productivity of mandarin orchard is positively influenced by number of years of involvement in mandarin farming, sprinkler irrigation system, prunning at effective time period while negatively influenced due to age, sex, education level of the respondent farmer, ethnic community (Janjati, Dalit, Chhetri, Brahmin), area of the mandarin orchard, weeding, manuring, intercropping and insect infestation. The productivity of mandarin orchard positively influenced with the number of years of involvement and prunning at effective time period are found significant at $1 \%$ level of significance. The productivity of mandarin orchard negatively influenced by manuring ( $30 \mathrm{~kg}$ or less) is significant at $10 \%$ level of significance which may be due to lack of sufficient manure in the orchard and due to non-uniform distribution of manure in orchard according to age of trees.

\section{Citrus decline}

The data reveals that decline of citrus orchard was positively influenced by insect infestation, intercropping, years of involvement and the frequency of old age trees above 20 years while negatively influenced by prunning at effective time period and available sprinkler irrigation system over canal irrigation system. The citrus decline due to years of involvement in mandarin farming is found to be significant at $1 \%$ level of significance through logistic analysis and significant at 5\% level of significance with analysis through margin effect after logistic [21-46].

\begin{tabular}{|c|c|c|c|c|}
\hline Productivity (mt/ha) & Coef. & Std. Err. & $\mathbf{t}$ value & $\mathbf{P}>|\mathbf{t}|$ \\
\hline Years of involvement*** & 0.06 & 0.02 & 2.82 & $<0.01$ \\
\hline Age & -0.02 & 0.02 & -1.40 & 0.17 \\
\hline Sex & -0.05 & 0.53 & -0.09 & 0.93 \\
\hline Ethnic community & -0.12 & 0.17 & -0.90 & 0.37 \\
\hline Education level & -0.11 & 0.18 & -0.61 & 0.55 \\
\hline Area of mandarin & -0.05 & 0.04 & -1.21 & 0.23 \\
\hline Available irrigation & 0.64 & 0.45 & 1.41 & 0.16 \\
\hline system & 1.09 & 0.39 & 2.80 & $<0.01$ \\
\hline Prunning timing*** & -0.36 & 0.63 & -0.58 & 0.57 \\
\hline Weed info & -1.20 & 0.69 & -1.74 & 0.09 \\
\hline Manuring* & -1.66 & 0.53 & -3.14 & $<0.01$ \\
\hline Inter cropping*** & -0.21 & 0.40 & -0.52 & 0.61 \\
\hline Insect infestation & \multicolumn{3}{|c}{}
\end{tabular}

Table 1: Dimensions of productivity of mandarin in Parbat Mandarin Block.

\begin{tabular}{|l|c|c|c|c|c|c|}
\hline \multicolumn{1}{|c|}{$\begin{array}{c}\text { Citrus } \\
\text { decline }\end{array}$} & $\begin{array}{c}\text { Odds } \\
\text { Ratio }\end{array}$ & $\begin{array}{c}\text { Std. } \\
\text { Err. }\end{array}$ & $\mathbf{Z}$ & $\mathbf{p}>|\mathbf{z}|$ & $\begin{array}{c}\mathbf{d y} / \\
\mathbf{d x}\end{array}$ & $\mathbf{p}>|\mathbf{z}|$ \\
\hline $\begin{array}{l}\text { Prunning } \\
\text { timing }\end{array}$ & 0.89 & 0.70 & -0.15 & 0.88 & -0.24 & 0.24 \\
\hline $\begin{array}{l}\text { Available } \\
\text { irrigation } \\
\text { system }\end{array}$ & 0.54 & 0.52 & -0.64 & 0.52 & -0.22 & 0.44 \\
\hline $\begin{array}{l}\text { Insect } \\
\text { infestation }\end{array}$ & 1.18 & 0.97 & 0.19 & 0.85 & -0.07 & 0.73 \\
\hline Intercropping & 2.51 & 2.63 & 0.87 & 0.38 & 0.13 & 0.65 \\
\hline $\begin{array}{l}\text { Years of } \\
\text { involvement }\end{array}$ & 1.21 & 0.08 & 2.86 & $0.004^{* * *}$ & 0.04 & $0.02^{* *}$ \\
\hline $\begin{array}{l}\text { Trees above } \\
\text { 20 years }\end{array}$ & 1.01 & 0.02 & 0.35 & 0.73 & 0.003 & 0.40 \\
\hline
\end{tabular}

Table 2: Different factors leading to citrus decline. 


\section{Conclusions}

Mandarin productivity is affected with age of the orchard was mainly due to the higher productive trees in the orchard. Yet, poor management practices had majorly led to the decline and lower productivity of the mandarin. The old aged plants replacement and regular prunning activities in effective time period is essential for longevity of orchard. Intercropping practices should be discarded and use of adequate amount of good quality manure and fertilizers, and micronutrients supplement is must. Proper crop calendar, insect traps or pheromones and disease control measures are essential for effective long term mandarin farming. The commercialization would be efficient and beneficent accessing different socio-factors and addressing the knowledge on different management practices.

\section{Bibliography}

1. MoAD. "Statistical information Nepalese Agriculture". Kathmandu: Government of Nepal (2016).

2. MoAD. Statistical Information on Nepalese Agriculture (2014).

3. Adhikari. "Causes of Citrus tree dieback, Citrus orchard decline and its management". Kirtipur (2013/14).

4. NCDP. (2015/16).

5. Acharya BB. "Citrus Cultivation Practices". Kritipur, Kathmandu: NCDP (2015).

6. Shrestha PA. "Development and outlook of citrus industry in Nepal". In proceeding of the second horticultural workshop. Horticulture society of Nepal (1998).

7. Gauchan D. "An Optimum Planning for Integrating Citrus in Nepalese Farming System". Chiangmai, Thailand: M.S.C Thesis, Chiangmai University (1994).

8. Gauchan D. "An Optimum Planning for Integrating Citrus in Nepalese Hill Farming System". Thesis, M. Sc. Graduate School, Chiangmai University, Chiangmai, Thailand (1994).

9. MEDEP. Orange Resource Survey of Banskharka VDC, Parbat District. parbat: Office Support Service (2013).

10. Acharya L. "Citrus: Orchard establishment and Management". Pokhara: Shree Complete Pvt. Pokhara (2004).
11. FAO. "Training Manual for Combating Citrus Decline Problem in Nepal". Kathmandu, Nepal: FAO (2011).

12. Knorr L., et al. "World citrus problems". V Nepal FAO Plant Protection Bulletin 19 (1971): 74-78.

13. Adhikari G. "Reason for Citrus Orchard Decline and its management (In Nepali)". National Citrus Development Program (2016/17).

14. Singh S and Naqvi S. Citrus Climate and Soil. Lucknow, India: International Book Distributing Co (2001).

15. Budathoki $\mathrm{K}$ and Pradhanang P. "Production Constraints in Western Hills of Nepal”. Lumle Agriculture Centre (1990).

16. Lewis C and Wicks W. "Orchard Management". Corvallis, Oregon: Oregon Agricultural College Press (1997).

17. Rajput C and R S H. Citriculture. Kalyani Publishers, India (2004).

18. Kaini B. "Rejuvenation of Declined citrus trees". Nepalese Horticulture (2004): 1-7.

19. CBS. Statistical Information on Nepalese Agriculture (2014).

20. CBS. Statistical Pocket Book of Nepal. Kathmandu, Nepal (2014).

21. Abbas IK., et al. "Citrus Greening Disease - A major cause of citrus decline in the world - A Review". (2007): 347.

22. Adhikari GN. Mandarin Production in Bhojpur District, A Case Study of Annapurna and Chhinamakhu VDC. T.U (1992).

23. Atreya P N. "Contribution of Mandarin on Livelihood Improvement of its Growers in Parbat District of Western Nepal". Nepalese Horticulture 10 (2015): 76-84.

24. Batool A., et al. "Citrus Greening Disease - A major cause of citrus decline in the world - A Review". (Prague)". Horticulture Science 347 (2007): 159-166.

25. Bové J. "Huanglongbing: A destructive, newly-emerging, century-old disease of citrus". Plant Pathology (2006): 88.

26. Chaudhary D., et al. "Role of Vermicompost in Sustainable Agriculture". Agriculture reviews. Agricultural Research Communication Centre, India (2004): 29-39. 
27. Dhakal D., et al. "Assessment of Lime and Lemon Production in Nepal". Journal of the Institute of Agriculture and Animal Science 23 (2002).

28. Dorji K., et al. "Adoption of Improved citrus Orchard management practices, a microstudy from Drujegang growers. Dugana, Bhutan". (2016).

29. FAO, GON, MOAC. "Training Manual on Combating Citrus Decline in Nepal". Food and Agriculture Organization of United Nations (2011).

30. Fateh F S., et al. "Prevalence of Citrus Decline in District Sargodha”. Pakistan Journal of Agricultural Sciences 54 (2017): $9-13$.

31. Kaini. Citrus in Nepal (2013).

32. Mandal R. "Weeds, Weedicides and Weed Control Principle and Practices". Bikaner, India: Agrobotanical Publisher (2000).

33. MoAD. "Statistical Information on Nepalese Agriculture 2012/2013". Kathmandu, Nepal: Ministry of Agriculture Development (2012/2013).

34. MoAD. "Statistical information on Nepalese agriculture 2013/14 (2070/071)". Singha Durbar, Kathmandu: Triveni Chhapakhana (2015/16).

35. MoAD/GON. "Statistical information on Nepalese Agriculture". Kathmandu: Ministry (2015/16).

36. NARDF. Project Compilation Report. Kathmandu, Nepal: National Agriculture Research and Development Fund (2010).

37. NARDF. "Project Compilation Report". Singh Durbar, Kathmandu, Nepal (2010).

38. Obreza T., et al. "Citrus fertilizer management on calcareous soils". Institute of Food and Agricultural Sciences, University of Florida (1993).
39. Paudel KP and Shrestha Y. Citrus Decline and its Management in Nepal (1995).

40. PMAMP. “Block/Zone Development Program Conducting Manual”. Ministry of Agriculture Development, Department of Agriculture (2017).

41. Poudel KP and Shreshtha YH. Citrus Decline and its Management in Nepal (1995).

42. Profile D. (2073/74).

43. Reddy T and Reddi G. Principle of Agronomy (3rd). New Delhi, India: Kalyani Publishers (2003).

44. Shrestha P and Verma S. "Development and Outlook of Citrus Industry in Nepal". In Proceedings of National Horticulture Workshop. Kathmandu, Nepal: Horticulture Society (1999): 48-57.

45. Singh D and Nepalia V. "Influence of Integrated nutrient management on Quality protein maize productivity and soils of Southern Rajasthan India". Journal of Agricultural Sciences (2009): 1020-1022.

46. Zubair M., et al. "Nutritional Assessment of Kinnow Mandarin Fruit (Citrus reticulata), Infected by Few Sucking Insect-Pests of Citrus". Pakistan Journal of Nutrition (2015).

Volume 3 Issue 10 October 2019

(C) All rights are reserved by Panth Bishnu Prasad and Dhakal Shiva Chandra. 